\title{
Interannual and seasonal variations of sand-dust events in Tarim Basin, China
}

\section{Lili Jin ( $269296387 @ q q . c o m$ )}

Yunnan University https://orcid.org/0000-0003-2256-001X

Qing He

Zhenjie Li

Mingzai Deng

Alim Abbas

Research Article

Keywords: Sand-dust, Floating dust, Sand blowing, Sandstorm, Tarim Basin

Posted Date: March 19th, 2021

DOI: https://doi.org/10.21203/rs.3.rs-327333/v1

License: @) (1) This work is licensed under a Creative Commons Attribution 4.0 International License. Read Full License 


\section{Abstract}

Dust events frequently occur in Tarim Basin (TB), China. However, research is scarce on the variation characteristics of sand-dust, floating dust, sand blowing, and sandstorms in the mountains, oases, and deserts in TB. Therefore, we conducted in-depth studies on the distributions and variations of dust events in TB. The results indicate that dust events tend to increase from south to north. The yearly sand-dust event occurrence rate trend is deserts $>$ oases $>$ mountainous regions. In spring, sand-dust, floating dust, sand blowing, and sandstorm days account for $35.9 \%, 36.0 \%, 38.5 \%$, and $47.1 \%$ of the whole year, while in summer they account for $33.6 \%, 33.5 \%, 43.8 \%$, and $60.3 \%$ of the whole year. From 1961 to 2015 , most stations (annual average > 30 stations) showed a downward linear trend in sand dust, floating dust, sand blowing, and sandstorms in TB. All types of sand-dust events in mountains and oases decreased substantially after 1975 to 1978. In spring and summer, the downward dust trends are the most obvious, which the largest annual average downward linear trend rates of floating dust, sand blowing, and sandstorms are $-0.33 \mathrm{~d} / \mathrm{yr}$ (QM station), $-0.21 \mathrm{~d} / \mathrm{yr}$ (TGLK station), and - $11 \mathrm{~d} / \mathrm{yr}$ (KP station), respectively, in spring, and $-0.28 \mathrm{~d} / \mathrm{yr}$ (QM station), $-0.17 \mathrm{~d} / \mathrm{yr}$ (TGLK station), and $-0.14 \mathrm{~d} / \mathrm{yr}$ (KP station), respectively, in summer. It is found that the decreasing and increasing trends of floating dust are the most obvious during sand-dust events. There is a significant positive correlation between wind speed and relative humidity in mountains, and a significant positive correlation between wind speed in oases.

\section{Introduction}

Central Asia, North America, and Australia have the high incidence of sand-dust weather in the world. Meanwhile, the northwest and north of China provide abundant sand sources for the occurrence of sand-dust weather, and they are among the most important regions with high incidences of sand-dust weather, in central Asia. Wind erosion desertification in China covers an area of $1.61 \times 10^{6} \mathrm{~km}^{2}$, mainly distributed in arid and semi-arid areas in the west. Xinjiang contains deserts amounting to an area of $4.3 \times 10^{5} \mathrm{~km}^{2}$ and the Gobi deserts have an area $3.26 \times 10^{5} \mathrm{~km}^{2}$. There are $2.13 \times 10^{5} \mathrm{~km}{ }^{2}$ of deserts in Inner Mongolia and $1.88 \times 10^{5} \mathrm{~km}^{2}$ of Gobi. Qinghai has $3.80 \times 10^{5} \mathrm{~km}^{2}$ of deserts and 3.70× $10^{5} \mathrm{~km}^{2}$ of Gobi (Tan, 2019; Han et al., 2012; Varga, 2020).

China's sand dust is mostly located north of the Yangtze River, more in the northwest than in the northeast, more in plains (or basins) than in mountains, and more in deserts and their edges than in any other region. The spatial distribution of sand dust in China is characterized by a large area, concentrated in highfrequency areas, and it has a close correlation with the degree of surface desertification (Chen, 2013). Sandstorm-prone areas in China are divided into seven sub-regions (northern Xinjiang, southern Xinjiang, Hexi, Qaidam Basin, Hetao, northeast China, and Qinghai-Tibet). Sandstorms and floating dust occur most frequently in southern Xinjiang, and sand blowing occurs most frequently in Hexi (Wang et al., 2003).

Since the 1920s, studies on the spatial and temporal distributions, causes, structure, monitoring, and countermeasures of sand dust have been carried out abroad. Research on sand dust has mainly focused on sub-Saharan Africa (Westphal et al., 1988; Helgren et al., 1987), while studies of sandstorm processes in East Asia, West Asia, and the Middle East began in recent decades (Kurosaki and Mikami, 2003; Wang et al., 2008; Gharibzadeh et al., 2017; Khusfi et al., 2020; Rezazadeh et al., 2013; Jung et al., 2019; Kwon et al., 2002; Chen et al., 2004). The highest frequency of global dust events takes place in Sudan, where the occurrence of suspended dust and severe dust storm is a maximum (Rezazadeh et al., 2013). Sand-dust weather is a frequent, disastrous weather in northern China during spring and summer, the direct causes of which are frequent cold air and cyclonic activities (Ye et al., 2000; Yang et al., 2019; Zhang et al., 2019; Zhang et al., 2019). Large-scale climate warming, the consequent strengthening of the zonal characteristics of atmospheric circulation, and increased precipitation in the mid-latitude zone constitute the climatic background for the decreased frequency of sand-dust weather in northern China in the last half century (Tao, 2007). Wang et al. (2018) found that the occurrences of dust storms, blowing dust, and floating dust over northern China decreased by $76.7 \%, 68.5 \%$, and $64.5 \%$ since the beginning of the 21 st century. The percentage of anthropogenic dust column burdens to the total mineral dust was $76.8 \%$ during 2007 to 2014 in eastern China, but was less than $9.2 \%$ in near-desert regions in northwestern China during the same period.

Over the past 50 years, the number of sandstorms in China has displayed a relatively obvious downward trend, while the number of strong sandstorms appears to have a relatively obvious upward trend (Lian, 2002). Wei et al. (2020) pointed out that by controlling the Kubuqi desert, the influence of sand-dust weather in the Beijing-Tianjin-Hebei Region area was effectively reduced. The sources of sandstorms in China are mainly concentrated in the deserts of southern Xinjiang and northern Xinjiang and their surrounding areas, Hexi Corridor of Gansu Province, dry deserts of Inner Mongolia, and Qaidam Basin of Qinghai Province (Qiu et al., 2001). Jia et al. (2019) pointed out that China's sand-dust emission sources are mainly the Taklimakan desert (TD) and Badain Jaran Desert. In the process of eastward transport, sand dust is lifted by high-altitude air streams which mixes with local man-made pollutants to turn into polluting sand dust; these, in turn, directly affect the eastern part of China. Dust weather, caused by interactions between wind and sand, is highly destructive and can result in serious consequences, such as poor air pollution, topsoil migration, reduced agricultural production, human and animal casualties, etc., making it a disastrous weather with a large scope of influence in China. Due to large-scale atmospheric circulation and weather systems, the influence of dust moves as the corresponding weather system moves, not only within the dust-source area, but for thousands to tens of thousands of kilometers, thereby affecting atmospheric environmental quality and ecological environments over exceedingly large areas. Indeed, such movement can dramatically increase the concentration of atmospheric particulate matter, causing different degrees of pollution along the route in which it travels (Lue et al., 2010; Liu et al., 2006; Zhao et al., 2008); such movement also influences meteorological elements. The appearance of sandstorms has obvious seasonal changes (Littmann,1991), which is related to the seasonal distribution of annual precipitation (Yu et al.,1993), vegetation cover, soil freezing, weather systems generating strong winds, and agricultural activities affecting the surface (Yu et al.,1993). For example, sandstorms in Mexico City have the highest frequency in March, where the rainfall has been less than $13 \mathrm{~mm}$ for the three consecutive, preceding months. Sandstorms frequently occur in Mexico City, although the lowest frequency of such storms occurs in September (Jauregui, 1989). The sandstorms in northwest India mainly occur from April to June, which is consistent with the frequency of sandstorms in Xinjiang, China.

The TD contains the highest amount of dust weather, and is a leading source of dust weather, in China. According to CALIPSO satellite data, the main TD aerosol subtype is dust (Meng et al., 2018). Dust events in the TD severely affect the air quality of most cities in northwest China, including eastern Xinjiang, Hexi Corridor, Guanzhong Basin, and northern regions of southwest China, leading to the mass concentrations of PM $\mathrm{P}_{10}$ (i.e. particulate matter with diameters 
smaller than 10 microns) on dust days increasing by 1 to $173 \%$ compared with non-dust days, while the mass concentration of $\mathrm{PM}_{2.5}$ (i.e. particulate matter with diameters smaller than 2.5 microns) increasing by 21 to $172 \%$ (Li et al., 2018). Therefore, it is necessary to understand the basic climatic characteristics of dust weather in the TD and surrounding areas. For example, Yang et al. (2015) analyzed observations of blowing dust events in the TD using 10 desertedge meteorological stations and two inner-desert meteorological stations. Pi et al. (2017) showed atmospheric dust events in central Asia, including a discussion on what is driving their findings. Although scholars have studied the dust weather in the TD, thorough analysis on the seasonal variation of different types of sand-dust events of the underlying surface has not yet been performed in Tarim Basin (TB).

Therefore, the spatial and temporal variations of sand-dust, floating dust, sand blowing, and sandstorm are analyzed here using data obtained at 42 meteorological stations (4, 1, and 37, respectively, from mountain, desert and oasis stations) in the TB. The analysis of the TB is helpful for further our understanding of the distribution characteristics of dust events. The remainder of this paper is organized as follows. In Sect. 2, we describe the study area and data. In Sect. 3, we present the spatial and temporal variations of dust events of the TB, including sand-dust, floating dust, sand blowing, and sandstorm. Finally, we give our conclusions based on this analysis in Sect. 4.

\section{Study Area And Data}

TB, the largest inland basin in China, lies between the Tianshan and Kunlun Mountains. Its widest extent from north to south is $520 \mathrm{~km}$, that from east to west is $1,400 \mathrm{~km}$, and it covers an area of more than $400,000 \mathrm{~km}^{2}$ (Fig. 1). TB has a warm temperate climate with an annual solar radiation budget of $575-627$ $\mathrm{kJ} / \mathrm{cm}^{2}$, with about 3,000 annual sunshine hours in the north, and fewer than 3,000 hours in the south. All regions contain windy and dusty weather. The average annual temperature is $9-11^{\circ} \mathrm{C}$, and the south is slightly warmer than the north. In winter, the east is colder than the west. In winter, the average temperature in TB is lower than $-20^{\circ} \mathrm{C}$ for only $1-2$ days. The average temperature in July in TB is $25-27^{\circ} \mathrm{C}$. The accumulated temperature varies greatly from year to year. The frost-free period is $200-210$ days in the north and 220 days in the south.

A dust event refers to a weather phenomenon in which sand particles and dust are suspended in the air due to wind, and move with the wind to make the air cloudy and reduce visibility. According to the horizontal visibility when dust weather occurs, dust weather is divided into five levels, namely floating dust, sand blowing, sand storm, strong sand storm, and extra-strong sand storm (GB/T $20480-2017)$. Floating dust means that there is no wind or the wind force is no more than level $3(3.4-5.4 \mathrm{~m} / \mathrm{s})$, sand particles and dust floating in the air make the air cloudy, and the horizontal visibility is less than $10 \mathrm{~km}$. Sand blowing means that the wind blows ground sand and dust to make the air quite cloudy, and the horizontal visibility is $1-10 \mathrm{~km}$. A sandstorm refers to wind blowing ground sand and dust to make the air very cloudy, with horizontal visibility $<1 \mathrm{~km}$; a strong sandstorm has a horizontal visibility $<500 \mathrm{~m}$; and an especially strong sandstorm has a horizontal visibility $<50 \mathrm{~m}$.

In this work, we define the occurrence of floating dust, sand blowing, or a sandstorm during a 24-hr period as 'dust weather'. Additionally, the occurrence of any two or three kinds of floating dust, sand blowing, and/or sandstorm is calculated according to a day of dust weather.

This study investigates trends in annual and seasons sand-dust, floating dust, sand dust and sandstorms days using the Mann-Kendall ( $\mathrm{M}-\mathrm{K}$ ) (Kendall, 1934, 1938; Mann, 1945).

\section{Results And Discussion 3.1 Spatial variations}

Figure 2 shows the distribution characteristics of the annual average sand dust, floating dust, sand blowing, and sandstorm days in mountain, oasis and desert regions in TB. The dust event distribution in TB features more in the south and hinterlands, and less in the north (Fig. 2). In mountainous regions, the maximum occurrence of annual average sand-dust, floating dust, sand blowing, and sandstorm days are $48.7 \mathrm{~d} / \mathrm{yr}$ (AHQ station), $42.7 \mathrm{~d} / \mathrm{yr}$ (WQ station), 14 $\mathrm{d} / \mathrm{yr}$ (AHQ station), and $8 \mathrm{~d} / \mathrm{yr}$ (AHQ station), respectively; in oasis regions, they are $195.8 \mathrm{~d} / \mathrm{yr}$ (HT station), $193.6 \mathrm{~d} / \mathrm{yr}$ (HT station), $66 \mathrm{~d} / \mathrm{yr}$ (PS station), and $38 \mathrm{~d} / \mathrm{yr}$ (XT station), respectively; and in desert regions, they are $48.9 \mathrm{~d} / \mathrm{yr}, 40.6 \mathrm{~d} / \mathrm{yr}, 23 \mathrm{~d} / \mathrm{yr}$, and $6 \mathrm{~d} / \mathrm{yr}$, respectively. These results indicate that floating dust accounts for the highest ratio of dust events in TB, comprising $87.7 \%, 98.9 \%$, and $83.3 \%$ in mountain, oasis, and desert regions, while sandstorms account for the lowest occurrence of dust events in TB, accounting for $16.4 \%, 19.4 \%$, and $12.3 \%$, respectively, in the three regions.

Figure 2(a) indicates that, interestingly, deserts (TZ station) do not contain the highest annual average amount of sand dust (48.9 d/yr); instead, the highest of $195.8 \mathrm{~d} / \mathrm{yr}$ occurs in HT (oasis, south of TB), while the lowest of $11.1 \mathrm{~d} / \mathrm{yr}$ occurs in TSKEG station (mountain, west of TB). There are $13 \mathrm{stations}$ with annual average sand-dust exceeding $100 \mathrm{~d} / \mathrm{yr}$ (YT, QM, MF, LP, HT, MY, CL, PS, SC, YJS, KP, BC, and KS station), all of which are oases. Figure 2(b) indicates that largest annual average floating dust occurrence rate is $193.6 \mathrm{~d} / \mathrm{yr}$ in HT station (oasis), while the lowest is $6.0 \mathrm{~d} / \mathrm{yr}$ in TSKEG station (mountain). There are 10 stations with annual average floating dust occurrence rates exceeding $100 \mathrm{~d} / \mathrm{yr}$ (YT, QM, MF, LP, HT, MY, CL, PS, SC, and XT station), all of which are oases. Figure 2(c) indicates that the largest annual average sand blowing occurrence rate is $66.0 \mathrm{~d} / \mathrm{yr}$ in PS station (oasis, south of TB), while the lowest is $0 \mathrm{~d} / \mathrm{yr}$ in TEGT station (mountain, west of TB). Figure 2(d) indicates that largest annual average sandstorm occurrence rate is $38.0 \mathrm{~d} / \mathrm{yr}$ in $\mathrm{XT}$ station (oasis, north of TB), while the lowest is $0 \mathrm{~d} / \mathrm{yr}$ in TEGT station (mountain). These results accord with those of Yang et al. (2015), who reported that TZ station (desert) did not have the highest occurrence of sandstorms from 1961 to 2010 in the desert, whereas Xiaotang station (oasis) has the highest occurrence of sandstorms.

\subsubsection{Seasonal spatial distribution of sand-dust}

Figures $3(a-d)$ show the spatial distributions of sand-dust days in spring, summer, autumn, and winter. The average maximum occurrence rates of sanddust are $70.3 \mathrm{~d} / \mathrm{yr}$ (HT station), $65.7 \mathrm{~d} / \mathrm{yr}$ (HT station), $36.3 \mathrm{~d} / \mathrm{yr}$ (HT station), and $23.5 \mathrm{~d} / \mathrm{yr}$ (HT station), respectively, accounting for $35.9 \%, 33.6 \%, 18.5 \%$, and $12.0 \%$, respectively, of the total annual average sand-dust days. The average minimum occurrence rates of sand-dust are $5.2 \mathrm{~d} / \mathrm{y}$ (TSKEG station), 2.5

Page $3 / 17$ 
$\mathrm{d} / \mathrm{y}$ (TSKEG station), $1.9 \mathrm{~d} / \mathrm{y}$ (YQ station, oasis, north of TB), and $0.4 \mathrm{~d} / \mathrm{y}$ (TEGT station), respectively, in spring, summer, autumn and winter, accounting for $47.0 \%, 22.2 \%, 8.8 \%$, and $2.4 \%$, respectively, of the total annual average sand-dust days. Spring and summer are the seasons with the highest rates of sanddust in TB, accounting for 69.5 to $77.0 \%$ of the annual sand-dust days; meanwhile, the sand-dust days in autumn and winter account for 23.0 to $30.5 \%$ of the total amount of annual sand-dust days.

\subsubsection{Seasonal spatial distribution of floating dust}

Figures $4(a-d)$ show the spatial distributions of floating-dust days in spring, summer, autumn, and winter. The average maximum occurrences of floatingdust days are $69.6 \mathrm{~d} / \mathrm{yr}, 64.9 \mathrm{~d} / \mathrm{yr}, 35.9 \mathrm{~d} / \mathrm{yr}$, and $23.2 \mathrm{~d} / \mathrm{yr}$, respectively, all at $\mathrm{HT}$, in spring, summer, autumn, and winter, accounting for $36.0 \%, 33.5 \%, 18.5 \%$, and $12.0 \%$, respectively, of the total annual average number of floating-dust days. The average minimum occurrences of floating-dust days are $2.3 \mathrm{~d} / \mathrm{yr}$ (TSKEG station), $0.5 \mathrm{~d} / \mathrm{yr}$ (YQ station), $0.7 \mathrm{~d} / \mathrm{yr}$ (YQ station), and $0.1 \mathrm{~d} / \mathrm{yr}$ (TSKEG station), respectively, in spring, summer, autumn, and winter, accounting for $37.8 \%, 5.9 \%, 8.2 \%$, and $0.9 \%$, respectively, of the total annual average number of floating-dust days. Spring and summer are the seasons with highest amounts of floating dust in TB, accounting for 69.5 to $77.8 \%$ of the total annual floating-dust days; meanwhile, the number of floating-dust days in autumn and winter account for 22.2 to $30.5 \%$ of the total annual floating dust days.

\subsubsection{Seasonal spatial distribution of sand blowing}

Figures $5(a-d)$ show the spatial distributions of sand-blowing days in spring, summer, autumn, and winter. The average maximum occurrence rates of sandblowing days are $25.4 \mathrm{~d} / \mathrm{yr}$ (PS station, oasis, south of TB), $28.9 \mathrm{~d} / \mathrm{yr}$ (TZ station, hinterland of TB), $10.3 \mathrm{~d} / \mathrm{yr}$ (PS station), and $4.1 \mathrm{~d} / \mathrm{yr}$ (MF station, oasis, south of TB), respectively, in spring, summer, autumn, and winter, accounting for $38.4 \%, 45.9 \%$, and $15.6 \%$, and $8.3 \%$, respectively, of the total annual average number of sand-blowing days. The average minimum occurrence rates of sand-blowing days are $0.3 \mathrm{~d}, 0.1 \mathrm{~d}, 0.02 \mathrm{~d}$, and $0.04 \mathrm{~d}$, respectively, all in TEGT station, in spring, summer, autumn, and winter, accounting for $56 \%, 32 \%, 4 \%$, and $8 \%$, respectively, of the total annual average number of sandblowing days. Spring and summer are the seasons with the highest amounts of sand blowing in TB, accounting for 79.0 to $87.0 \%$ of the total annual number of sand-blowing days; meanwhile, the number of sand-blowing days in autumn and winter account for 13.0 to $21.0 \%$ of the total annual number of sandblowing days.

\subsubsection{Seasonal spatial distribution of sandstorms}

Figures $6(a-d)$ shows the spatial distributions of sandstorm days in spring, summer, autumn, and winter. The average maximum occurrence rates of sandstorm days are $17.9 \mathrm{~d} / \mathrm{yr}$ (XT station), $22.9 \mathrm{~d} / \mathrm{yr}$ (XT station), $4.4 \mathrm{~d} / \mathrm{yr}$ (XT station), and $1.3 \mathrm{~d} / \mathrm{yr}$ (MF station), respectively, in spring, summer, autumn, and winter, accounting for $39.2 \%, 50.1 \%, 50 \%$, and $50 \%$, respectively, of the total annual average number of sandstorm days. The average minimum occurrence rates of sandstorm days are $0 \mathrm{~d} / \mathrm{y}, 0 \mathrm{~d} / \mathrm{y}, 0.02 \mathrm{~d} / \mathrm{y}$, and $0.02 \mathrm{~d} / \mathrm{y}$, respectively, all at TEGT station, in spring, summer, autumn, and winter, accounting for $0 \%, 0$ $\%, 50 \%$, and $50 \%$, respectively, of the total annual average number of sandstorms days. Spring and summer are the seasons with the highest amounts of sandstorms in TB, accounting for 0 to $87.7 \%$ of the total annual number of sandstorm days; meanwhile, the number of sandstorm days in autumn and winter account for 12.3 to $100 \%$ of the total annual number of sandstorm days.

\subsection{Trend variations}

Figure 7 shows that 38 stations, 40 stations, 32 stations and 36 stations present a downward trend, and only 1 station, 2 stations, 4 stations and 1 station present an upward trend, of sand-dust days, floating dust days, sand blowing days and sandstorm days in all seasons. Among the stations that negative trend have 38, 37, 23 and 33 stations passed 99\% confidence level, of sand-dust days, floating dust days, sand blowing days and sandstorm days in all seasons. Positive trend have 2, 1, 3 and 0 stations passed 99\% confidence level, of sand-dust days, floating dust days, sand blowing days and sandstorm days in all seasons.

The largest annual average downward linear trend rates are $-2.83 \mathrm{~d} / \mathrm{yr}$ (QM station, oasis, southwest of TB), -2.80 d/yr (QM station), -1.50 d/yr (TGLK station, oasis, northeast of TB), and $-0.87 \mathrm{~d} / \mathrm{yf}$ (KP station, oasis, west of TB), respectively, for sand-dust, floating dust, sand blowing, and sandstorms in TB. Previous studies noted that the frequencies of sandstorms, sand blowing and floating dust decreased by as much as $76.7 \%, 68.5 \%$, and $64.5 \%$, respectively, near the source regions around the TD, Gobi Desert, and Badain Jaran Desert (Wang et al., 2018). However, the largest annual average upward trends found here are $4.0 \mathrm{~d} / \mathrm{yr}, 5.1 \mathrm{~d} / \mathrm{yr}, 1.6 \mathrm{~d} / \mathrm{yr}$, and $0.2 \mathrm{~d} / \mathrm{yr}$, respectively, all at TZ station, for sand dust, floating dust, sand blowing, and sandstorms in TB.

\subsubsection{Seasonal trend variations of sand dust}

Figure 8 shows that 36 stations, 36 stations, 34 stations and 0 station present a downward trend, and only 1 station, 1 station, 1 station and 0 station present an upward trend, of spring, summer, autumn and winter in sand-dust days. Among the stations that negative trend have $30,32,21$ and 0 stations passed $99 \%$ confidence level, of spring, summer, autumn and winter in sand-dust days. Positive trend all have 0 station passed $99 \%$ confidence level, of spring, summer, autumn and winter in sand-dust days.

The largest annual average downward linear trend rates of sand-dust are - $0.33 \mathrm{~d} / \mathrm{yr}$ (QM station), $-0.27 \mathrm{~d} / \mathrm{yr}$ (QM station), and - $0.19 \mathrm{~d} / \mathrm{yr}$ (QM station), respectively, in spring, summer, and autumn in TB. However, the largest annual average upward trends of sand-dust are $0 \mathrm{~d} / \mathrm{yr}, 0.02 \mathrm{~d} / \mathrm{yr}$ (LT station, oasis, north of TB), $0.03 \mathrm{~d} / \mathrm{yr}$ (LT station), respectively, in spring, summer, and autumn in TB.

\subsubsection{Seasonal trend variations of floating dust}


Figure 9 shows that 34 stations, 33 stations, 29 stations and 32 stations present a downward trend, and only 3 stations, 2 stations, 1 station and 1 station present an upward trend, of spring, summer, autumn and winter in floating dust days. Among the stations that negative trend have $25,29,23$ and 22 stations passed $99 \%$ confidence level, of spring, summer, autumn and winter in floating dust days. Positive trend have 1, 0, 3 and 0 stations passed $99 \%$ confidence level, of spring, summer, autumn and winter in floating dust days.

The largest annual average downward linear trend rates of floating dust are $-0.33 \mathrm{~d} / \mathrm{yr}$ (QM station), $-0.28 \mathrm{~d} / \mathrm{yr}$ (QM station), $-0.19 \mathrm{~d} / \mathrm{yr}$ (QM station), and $0.18 \mathrm{~d} / \mathrm{yr}$ (HT station), respectively, in spring, summer, autumn, and winter in TB. However, the largest annual average upward trends of floating dust are 0.67 $\mathrm{d} / \mathrm{yr}, 0.36 \mathrm{~d} / \mathrm{yr}, 0.33 \mathrm{~d} / \mathrm{yr}$, and $0.17 \mathrm{~d} / \mathrm{yr}$, respectively, all at TZ station, in spring, summer, autumn, and winter in TB.

\subsubsection{Seasonal trend variations of sand blowing}

Figure 10 shows that 24 stations, 26 stations, 19 stations and 9 stations present a downward trend, and only 5 stations, 4 stations, 2 stations and 0 station present an upward trend, of spring, summer, autumn and winter in sand blowing days. Among the stations that negative trend have $14,16,16$ and 4 stations passed $99 \%$ confidence level, of spring, summer, autumn and winter in sand blowing days. Positive trend have 2, 1, 1 and 0 stations passed $99 \%$ confidence level, of spring, summer, autumn and winter in sand blowing days.

The largest annual average downward linear trend rates of sand blowing are $-0.21 \mathrm{~d} / \mathrm{yr}$ (TGLK station), $-0.17 \mathrm{~d} / \mathrm{yr}$ (TGLK station), $-0.07 \mathrm{~d} / \mathrm{yr}$ (TGLK station), and $-0.04 \mathrm{~d} / \mathrm{yr}$ (PS station, oasis, southwest of TB), respectively, in spring, summer, autumn, and winter in TB. However, the largest annual average upward trends of sand blowing are $0.39 \mathrm{~d} / \mathrm{yr}$ (TZ station), $0.77 \mathrm{~d} / \mathrm{yr}$ (TZ station), $0.05 \mathrm{~d} / \mathrm{yr}$ (TZ station), and $1.10 \mathrm{~d} / \mathrm{yr}$ (WS station, oasis, west of TB), respectively, in spring, summer, autumn, and winter in TB.

\subsubsection{Seasonal trend variations of sandstorms}

Figure 11 shows that 30 stations, 17 stations, 4 stations and 1 stations present a downward trend, and all 0 station present an upward trend, of spring, summer, autumn and winter in sandstorms days. Among the stations that negative trend have $29,22,4$ and 1 stations passed $99 \%$ confidence level, of spring, summer, autumn and winter in sandstorms days.

The largest annual average downward linear trend rates of sandstorms are $-0.11 \mathrm{~d} / \mathrm{yr}$ (KP station, oasis, west of TB), $-0.14 \mathrm{~d} / \mathrm{yr}$ (KP station), $-0.02 \mathrm{~d} / \mathrm{yr}$ (YPH station, oasis, west of TB), and - $0.01 \mathrm{~d} / \mathrm{yr}$ (MF station), respectively, in spring, summer, autumn, and winter in TB.

\subsection{Temporal variations}

\subsubsection{Interannual variations}

Figure 12 and Table 1 show that the sand-dust, floating dust, sand blowing, and sandstorm days present decreasing trends from 1961 to 2015 in mountainous and oasis regions. The annual trend values are $-0.51,-0.38,-0.07$, and $-0.09 \mathrm{~d} / \mathrm{yr}$ (the trend is significant at the $99 \%$ level), respectively in mountains, and $-1.23,-1.17,-0.32$, and $-0.25 \mathrm{~d} / \mathrm{yr}$ (the trend is significant at the $99 \%$ level), respectively, in oases. However, the sand-dust, floating dust, and sand blowing present increasing trends from 1996 to 2015 in desert regions, with annual trend values of 4.00, 5.10, and 1.62 d/yr, respectively. It can be seen that the decreasing and increasing trends of floating dust are the most obvious during sand-dust events. In spring and summer, the trend values are larger, while in autumn and winter, they are smaller in mountainous and oasis regions. However, in deserts, the trend values of floating dust are larger in spring, summer, and autumn, and smaller in winter; the trend values of sand blowing are larger in summer, and smaller in other seasons (Table 1).

On average, the maximum values of sand-dust, floating dust, sand blowing and sandstorm days are $62.0 \mathrm{~d}, 51.3 \mathrm{~d}, 11.3 \mathrm{~d}$, and $9.3 \mathrm{~d}$, respectively, in 1978 , 1978, 1975, and 1976 in mountains; 147.7 d, 133.6 d, 39.9 d, and 19.9 d, respectively, in 1979, 1979, 1980, and 1966, in oases; and 188 d, 172 d, 95 d, and 36 d, respectively, in 2010, 2010, 2009, and 1998, in deserts. The annual variations of sand dust, floating dust, sand blowing, and sandstorm in mountains are similar to those in oasis; that is, they were higher before 1985, and smaller thereafter. In other words, before the mid-1980s, it was the peak of sand-dust, floating dust, sand blowing, sandstorms, and after that, it was the low period.

Table 1 shows that the sand-dust is positively correlated with wind speed, air temperature, and relative humidity over different surfaces. A further analysis found that the annual and spring sand- dust shows a positive correlation between wind speed, air temperature and relative humidity in mountains. However, summer, autumn and winter sand-dust shows a positive correlation between relative humidity. Annual, summer and autumn sand-dust shows a positive correlation between wind speed, air temperature and relative humidity, relatively in desert. However, spring and winter sand-dust shows no correlation with wind speed, air temperature and relative humidity in desert. Interestingly, annual and seasons sand-dust shows a positive correlation between wind speed. Moreover, sand-dust shows a positive correlation between air temperature in oases in autumn.

\section{Table 1}

Trend of sand-dust, floating dust, sand blowing, and sandstorms, and the correlation coefficients between the various meteorological elements in mountains, deserts, and oases in terms of their annual values, and those during spring, summer, autumn, and winter. 


\begin{tabular}{|c|c|c|c|c|c|c|}
\hline & & Annual & Spring & Summer & Autumn & Winter \\
\hline \multicolumn{7}{|l|}{ Trend } \\
\hline \multirow[t]{3}{*}{ Sand-dust } & Mountain & $-0.51^{\text {** }}$ & $-0.08^{* *}$ & $-0.05^{\star *}$ & $-0.03^{* *}$ & $-0.01^{* k}$ \\
\hline & Desert & $4.00^{\star \star}$ & $0.78^{\star *}$ & 0.67 & $1.00^{\star *}$ & $1.00^{*}$ \\
\hline & Oasis & $-1.23^{\star *}$ & $-0.51^{\text {** }}$ & $-0.45^{* *}$ & $-0.24^{* *}$ & $-0.21^{* k}$ \\
\hline \multirow[t]{3}{*}{ Floating dust } & Mountain & $-0.38^{\star *}$ & $-0.31^{* *}$ & $-0.14^{* *}$ & $-0.10^{\text {** }}$ & $-0.07^{* *}$ \\
\hline & Desert & $5.10^{\star \star}$ & $2.00^{* \star}$ & 1.08 & $1.00^{\star *}$ & 0.50 \\
\hline & Oasis & $-1.17^{\star \star}$ & $-0.42^{* *}$ & $-0.34^{\star *}$ & $-0.20^{\star *}$ & $-0.18^{* *}$ \\
\hline \multirow[t]{3}{*}{ Sand blowing } & Mountain & $-0.07^{\star *}$ & $-0.04^{* *}$ & $-0.06^{* *}$ & $-0.02^{* *}$ & $-0.01^{*}$ \\
\hline & Desert & $1.62^{\star *}$ & 0.20 & $0.91^{* *}$ & 0.09 & 0.14 \\
\hline & Oasis & $-0.32^{\star *}$ & $-0.12^{* *}$ & $-0.14^{* *}$ & $-0.05^{* *}$ & $-0.04^{* k}$ \\
\hline \multirow[t]{3}{*}{ Sandstorm } & Mountain & $-0.09^{* *}$ & $-0.06^{* *}$ & $-0.03^{* *}$ & $-0.02^{\text {** }}$ & $-0.01^{* *}$ \\
\hline & Desert & - & - & - & - & - \\
\hline & Oasis & $-0.25^{* *}$ & $-0.13^{* *}$ & $-0.10^{\star *}$ & $-0.02^{* *}$ & $-0.01^{* *}$ \\
\hline \multicolumn{7}{|c|}{ Correlation coefficients between sand-dust and meteorological elements } \\
\hline \multirow[t]{3}{*}{ Wind speed } & Mountain & $0.768^{b}$ & $0.684^{\mathrm{a}}$ & $0.594^{c}$ & & \\
\hline & Desert & $0.647^{\mathrm{c}}$ & & & & \\
\hline & Oasis & $0.695^{c}$ & $0.807^{b}$ & $0.752^{b}$ & $0.603^{c}$ & $0.466^{\mathrm{b}}$ \\
\hline \multirow[t]{3}{*}{ Air temperature } & Mountain & $0.801^{\mathrm{c}}$ & $0.548^{\mathrm{c}}$ & & & \\
\hline & Desert & & & $0.472^{b}$ & & \\
\hline & Oasis & & & & $0.715^{b}$ & \\
\hline \multirow[t]{3}{*}{ Relative humidity } & Mountain & $0.633^{a}$ & $0.645^{\mathrm{b}}$ & $0.646^{\mathrm{b}}$ & $0.453^{\mathrm{c}}$ & $0.454^{\mathrm{c}}$ \\
\hline & Desert & & & & $0.495^{b}$ & \\
\hline & Oasis & & & & & \\
\hline
\end{tabular}

NB: Bold values indicate that the trend is significant at the $90 \%$ level; Bold values and single star indicate that the trend is significant at the $95 \%$ level; Bold values and double star indicate that the trend is significant at the $99 \%$ level; Letter a indicate the three independent variables that comes into the regression equation; Letter $\mathrm{b}$ indicate the two independent variables that comes into the regression equation; Letter $\mathrm{c}$ is the one independent variable that comes into the regression equation.

\subsubsection{Annual variations}

Figure 13 shows that the numbers of sand-dust, floating dust, sand blowing, and sandstorm days above the different underlying surfaces in TB from January to December follow the ascending trend of deserts > oases > mountainous regions. Figure 13 also shows that sand dust, floating dust, sand blowing, and sandstorms mainly occur from March to October in TB, accounting for $90.9 \%, 88.2 \%, 89.0 \%$, and $87.0 \%$, respectively, in mountains; $86.7 \%$, $85.2 \%, 95.6 \%$, and $97.8 \%$, respectively, in deserts; and $85.5 \%, 84.5 \%, 90.5 \%$, and $94.0 \%$, respectively, in oases.

Figure 13. Annual variations of sand-dust days, floating dust days, sand blowing days, and sandstorm days from 1961 to 2015 in mountainous regions, desert regions, and oasis regions in TB.

\section{Conclusions}

Using observational data obtained at 41 stations in TB, we analyzed the spatial and temporal distribution characteristics of sand-dust, floating dust, sand blowing, and sandstorms in mountains, oases, and deserts in this region. Our main conclusions are summarized as follows.

(1) Dust weather occurs frequently in southern regions of TD. The number of dust days (sand-dust, floating dust, sand blowing, and sandstorms) follows the order of deserts > oases > mountains. In the sand-dust event, the main is floating dust. The largest number of sand-dust, floating dust, sand blowing, and sandstorm days are at HT station (195.8 d), HT station (193.6 d), PS station (66 d), and XT station (38 d), all in oases, around TD. The fewest number of 
sand-dust, floating dust, sand blowing, and sandstorm days are at TSKEG station ( $11.1 \mathrm{~d})$, TSKEG station ( $6 \mathrm{~d})$, TEGT station (0 d), and TEGT station (0 d), all in mountains, west of TD.

(2) Spring and summer represent the high-dust seasons in TD. In spring, the average maximum number of sand-dust, floating dust, sand blowing, and sandstorm days are $70.3 \mathrm{~d}, 69.6 \mathrm{~d}, 25.4 \mathrm{~d}$, and $17.9 \mathrm{~d}$, respectively, at HT station, HT station, PS station, and XT station (all oases). In summer, the average maximum number of sand-dust, floating dust, sand blowing, and sandstorm days are $65.7 \mathrm{~d}, 64.9 \mathrm{~d}, 28.9 \mathrm{~d}$, and $22.9 \mathrm{~d}$, respectively, at HT station, HT station, TZ station, and XT station (oases and deserts). In autumn, the average maximum number of sand-dust, floating dust, sand blowing, and sandstorm days are $36.3 \mathrm{~d}, 30.9 \mathrm{~d}, 10.3 \mathrm{~d}$, and $4.4 \mathrm{~d}$, respectively, at HT station, HT station, PS station, and XT station (all oases). In winter, the average maximum number of sand-dust, floating dust, sand blowing, and sandstorm days are $23.5 \mathrm{~d}, 23.2 \mathrm{~d}, 4.1 \mathrm{~d}$, and $1.3 \mathrm{~d}$, respectively, at HT station, HT station, MF station, and MF station (all oases).

(3) By the results of $\mathrm{M}-\mathrm{K}$ analysis, from 1961 to 2015, 38, 40,32, and 36 stations showed downward linear trends in sand-dust, floating dust, sand blowing, and sandstorm events in TB, passed $99 \%$ confidence level accounting for $100 \%, 93 \%, 72 \%$ and $92 \%$, respectively. The largest annual average downward linear trend stations are QM station (-2.83 d/yr), QM station (-2.80 d/yr), TGLK station (-1.50 d/yr), and KP station (-0.87 d/yr), all of which are located in oases. In total, $36,34,34$, and 0 stations in spring; $36,33,26$, and 17 stations in summer; $34,29,19$, and 4 stations in autumn; and $0,32,9$, and 1 stations in winter showed downward linear trends in sand-dust, floating dust, sand blowing, and sandstorm events in TB. These downtrend sites are all associated with oases, while uptrend sites are located in oasis and deserts.

(4) The annual trend values of sand-dust, floating dust, sand blowing, and sandstorm are $-0.51,-0.38,-0.07$, and $-0.09 \mathrm{~d} / \mathrm{yr}$, respectively in mountains, and $-1.23,-1.17,-0.32$, and $-0.25 \mathrm{~d} / \mathrm{yr}$, respectively, in oases. However, the annual trend values of sand-dust, floating dust, and sand blowing are $4.00,5.10$, and $1.62 \mathrm{~d} / \mathrm{yr}$, respectively, in deserts. March to September is the peak season for dust events, accounting for 87.0 to $90.9 \%, 85.2$ to $97.8 \%$, and 84.5 to $94.0 \%$, respectively, of the whole year in mountains, deserts, and oases. The occurrence of sand-dust events is closely related to wind speed and relative humidity in mountains, and is closely related to wind speed in oases, while, is complex in desert.

\section{Declarations}

Acknowledgments Thanks are expressed to the Xinjiang Meteorological Bureau for providing the data used in this research. This work was financially supported by the National Natural Science

Foundation of China (Grant No. 42030612, 41830968) and the Second Tibetan Plateau Scientific Expedition and Research (STEP) program (Grant No.2019QZI

Authors' contributions Participation of Qing He and Zhenjie Li included data collection; the participation of MingZai Deng and Alimabbas included drawing Figures 1-11; and the participation of Lili Jin included writing the article and helping to analyze the results.

Data availability The data used in this research are available from the corresponding author upon reasonable request.

\section{Compliance with ethical standards Ethics approval}

Ethics approval The authors confirm that this article is original research and has not been published or presented previously in any journal or conference in any language (in whole or in part).

Consent to participate and consent to publish The authors declare that they have consent consented to participate and consented to publish.

\section{References}

1. Chen, Y., 2013. Study on the variation characteristics and causes of dust weather in Northern China in recent ten years. Lanzhou: Lanzhou University. (in Chinese)

2. Chen,Y.S., Sheen, P.C., Chen,E.R., Liu,Y.K., Wu,T.N., Yang,C.Y., 2004. Effects of Asian dust storm events on daily mortality in Taipei, Taiwan. Environ. Res. 95 (2004), 151-155.doi:10.1006/enrs.2002.4377

3. Gharibzadeh, M., Alam, K., Bidokhti, A.A., Abedini, Y., Masoumi, A., 2017. Radiative effects and optical properties of aerosol during two dust events in 2013 over Zanjan, Iran. Aerosol Air Qual. Res. 17: 888-898

4. Han, L.Y., Zhang, Q., Guo, N., Ma, P. L., Han, T., Wan, X., 2012. Temporal and spatial characteristics of dust events in Northwest China. Journal of Desert Research, 32(02),454- (in Chinese)

5. Helgren, D.M., Prospero, J. M., 1987. Wind velocities associated with dust deflation events in the western Sahara. Clim. Appl. Meteorol. 26(9),1147-1151.

6. Jáuregui, E.,1989. The dust storms of Mexico City. International Journal of Climatology 9(2), 169-

7. Jia, R., Liu, Y. Z., Wu, C. Q., Zhu, Q. Z., Wang, B., 2019. Three-dimensional distribution and transport process of dust aerosols over China from 2007 to 2017. Journal of Desert Research,39(06),108- (in Chinese)

8. Jung, M., Son, S.W., Kim, H.C., Kim, S.W., Park, R.J., Chen, D.L.,2019. Contrasting synoptic weather patterns between non-dust high particulate matter events and Asian dust events in Seoul, South Korea. Environ. (2019), doi: https://doi.org/10.1016/j.atmosenv.2019.116864.

9. Kendall, M.G., 1934. Rank correlation methods. Br J Psychol 25(1):86-91.

10. Kendall, M.G., 1938. A new measure of rank correlation. Biometrika 30(1/2):81-93.

11. Khusfi, Z.E., Khosroshahi, M., Roustaei, F., Mirakbari, M., 2020. Spatial and seasonal variations of sand-dust events and their relation to atmospheric conditions and vegetation cover in semi-arid regions of central Iran. Geoderma 365 (2020) 114225

Page $7 / 17$ 
12. Kurosaki, Y., Mikami, M., 2003. Recent frequent dust events and their relation to surface wind in East Asia. Res. Lett. 30(14),1736, doi:10.1029/2003GL017261

13. Kwon, H.J., Cho, S.H., Chun, Y., Lagarde, A.F., ran Pershagen, G., 2002. Effects of the Asian dust events on daily mortality in Seoul, Korea. Res. $90(1), 1-5$.

14. Li, X.Y., Liu, X.D., Yin, Z.Y., 2018. The impacts of Taklimakan dust events on Chinese urban air quality in 2015. Atmosphere, 9, 281 doi:10.3390/atmos 9070281

15. Lian, L. S., 2002. Temporal and spatial distribution characteristics and analysis of causes of sand-dust storms in the North of China. Nature Journal, 25 (6), 335- (in Chinese)

16. Littmann, T., 1991. Dust storm frequency in Asia: climatic control and variability. International Journal of Climatology,11(4),393-

17. Liu, C. M., Young, C. Y., Lee, Y. C., 2006. Influence of Asian dust storms on air quality in Taiwan. Science of the Total Environment,368(2-3),884-

18. Lue, Y. L., Liu, L. Y., Hu, X., Wang, L., Guo, L.L.,Gao, S.Y., Zhang, X.X., Tang, Y., Qu, Z.Q., Cao, H.W., Jia, Z.J., Xu, H.Y., Yang, Y.Y.,2010.Characteristics and provenance of dustfall during an unusual floating dust event. Atmospheric Environment,44(29),3477-

19. Mann, H.B., 1945, Nonparametric tests against trend. Econometrica 13(3),245-25.

20. Pi, H. W., Sharratt, B., Lei, J. Q., 2017. Atmospheric dust events in central Asia: Relationship to wind, soil type, and land use. Journal of Geophysical Research: Atmospheres,122,6652-6671.

21. Qiu, X. F., Ceng, Y., Miu, Q. L., 2001. Temporal-spatial distribution as well as Tracks and source areas of sand-dust storms in China. Acta Geographica Sinica,2001(03),316- (in Chinese)

22. Rezazadeh, M. Irannejad, P. Shao, Y., 2013. Climatology of the Middle East dust events. Aeolian Research,10,103-

23. Tan, Z.X., 2019. Numerical simulation study on boundary layer height characteristics and its impact on dust weather in arid and semi-arid regions of northwest China. Lanzhou: Lanzhou University. (in Chinese)

24. Tao, J. H., 2007. Study on climate characteristics and impacts of dust weather in northwest China. Nanjing: Nanjing University of Information Engineering.

25. Varga, G., 2020. Changing nature of Saharan dust deposition in the Carpathian Basin (Central Europe): 40 years of identified North African dust events (1979-2018). Environment International, 139(2020)105712 https://doi.org/10.1016/j.envint.2020.105712

26. Wang, S.G., Wang, J.Y., Zhou, Z. J., Shang, K. Z., Yang, D.B., Zhao, Z. S., 2003. Regional characteristic of dust event in China. Acta Geographica Sinica,2003(02),193- (in Chinese)

27. Wang, X., Huang, J.P., Ji, M.X., Higuchi, K., 2008. Variability of East Asia dust events and their long-term trend. Atmospheric Environment 42 (2008) $3156-3165$.

28. Wang, X., Liu, J., Che, H. Z., Ji, F., Liu, J. J., 2018. Spatial and temporal evolution of natural and anthropogenic dust events over northern China. Scientific Reports, 8,2141 | doi:10.1038/s41598-018-20382-5

29. Wei, W., Zhang, W. D., Chen, H. S., Ren, Y. Z., Pi, D. Q., Wu, J. B., Chen, T. T., Xiao, L. H., Luo, B. G., Yan, P. Z., 2020. Influence of desertification control in Hobq Desert on air quality in Beijing-Tianjin-Hebei region: a simulation case of dust weather on 3-6, May 2017. Journal of Desert Research,40(01),77- (in Chinese)

30. Westphal, D. L., Toon, O. B., Carlson, T.N., 1988. A case study of mobilization and transport of Saharan dust. Journal of the Atmospheric Sciences 45(15), 2145-

31. Yang, M. Z., Zhu, X. Y., Ai, W. X., Song, W. L., 2019. Multi-factor prediction of spring dust weather frequency in northern China. Science and Technology Herald, 37 (20), 19- (in Chinese)

32. Ye, D. Z., Chou, J. F., Liu, J. Y., Zhang, Z.X., Wang, Y.M., Zhou, Z.J., Ju, H.B., Huang, Q., 2000. Causes of sand-storm weather in North China and countermeasures. Acta Geographica Sinica, 55 (5): 513-521. (in Chinese)

33. Yu, B., Hesse, P. P., Neil, D. T., 1993. The relationship between antecedent regional rainfall conditions and the occurrence of dust events at Mildura, Australia. Journal of arid environments,24(2),109-

34. Zhang, Y., Wang, H. B., Zuo, H. J., Yan, M., 2019. Identify high frequent dust areas and their sources in spring in the Northwest of China. China Environmental Science, 39 (10),4065- (in Chinese)

35. Zhang, Z. J., Yi, Y. H., Chen, B., Du, H., 2019. Effect of dust weather on urban air quality over northern China in spring of 2018 and its weather analysis. Journal of Desert Research, 39(06),13- (in Chinese)

36. Zhao, T. L., Gong, S. L., Zhang, X. Y., Jaffe, D.A., 2008. Asian dust storm influence on north American ambient PM levels: observational evidence and controlling factors. Atmospheric Chemistry and Physics,8, 2717-

\section{Figures}




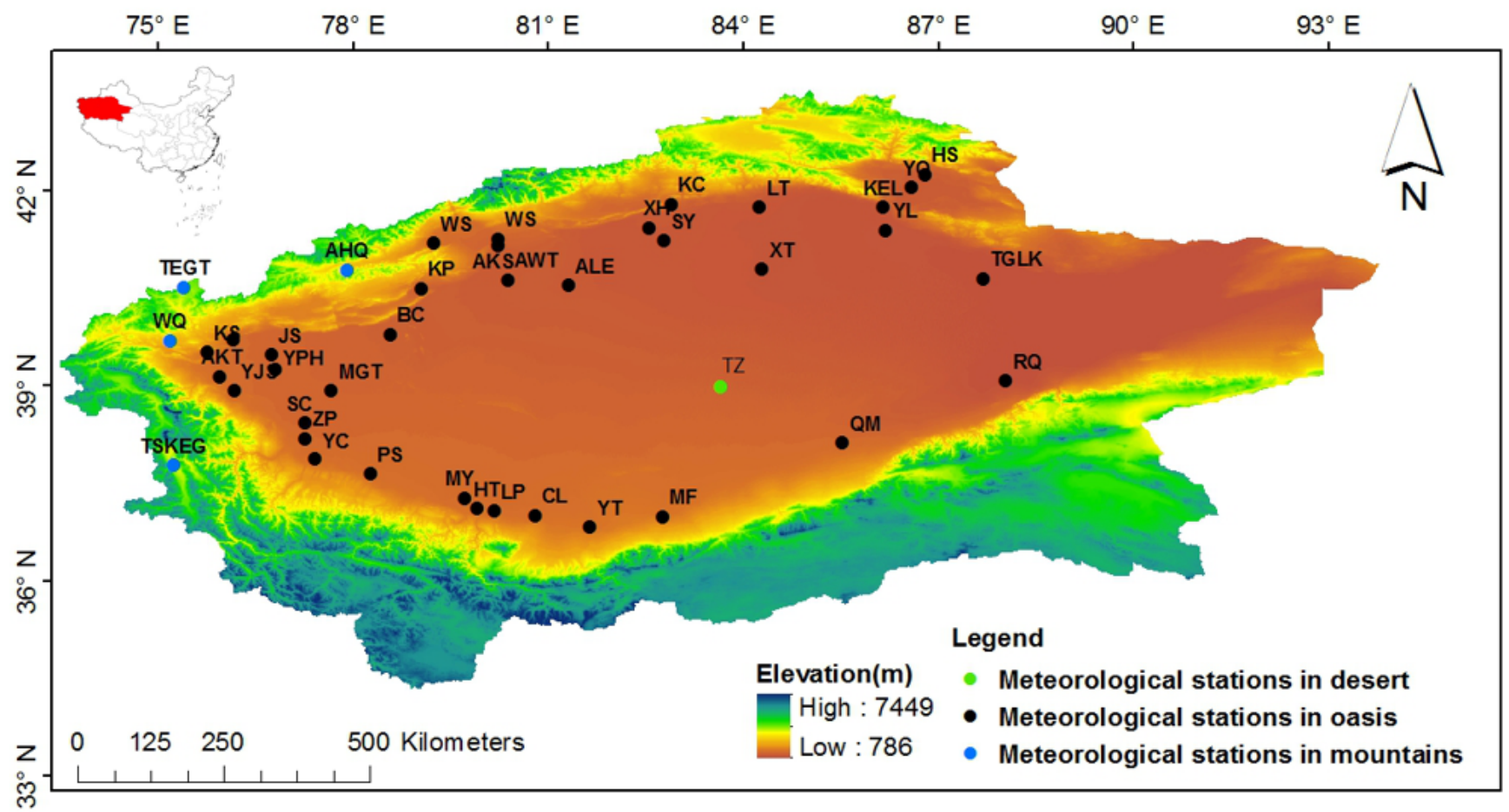

Figure 1

Spatial distribution of the meteorological stations in TB.
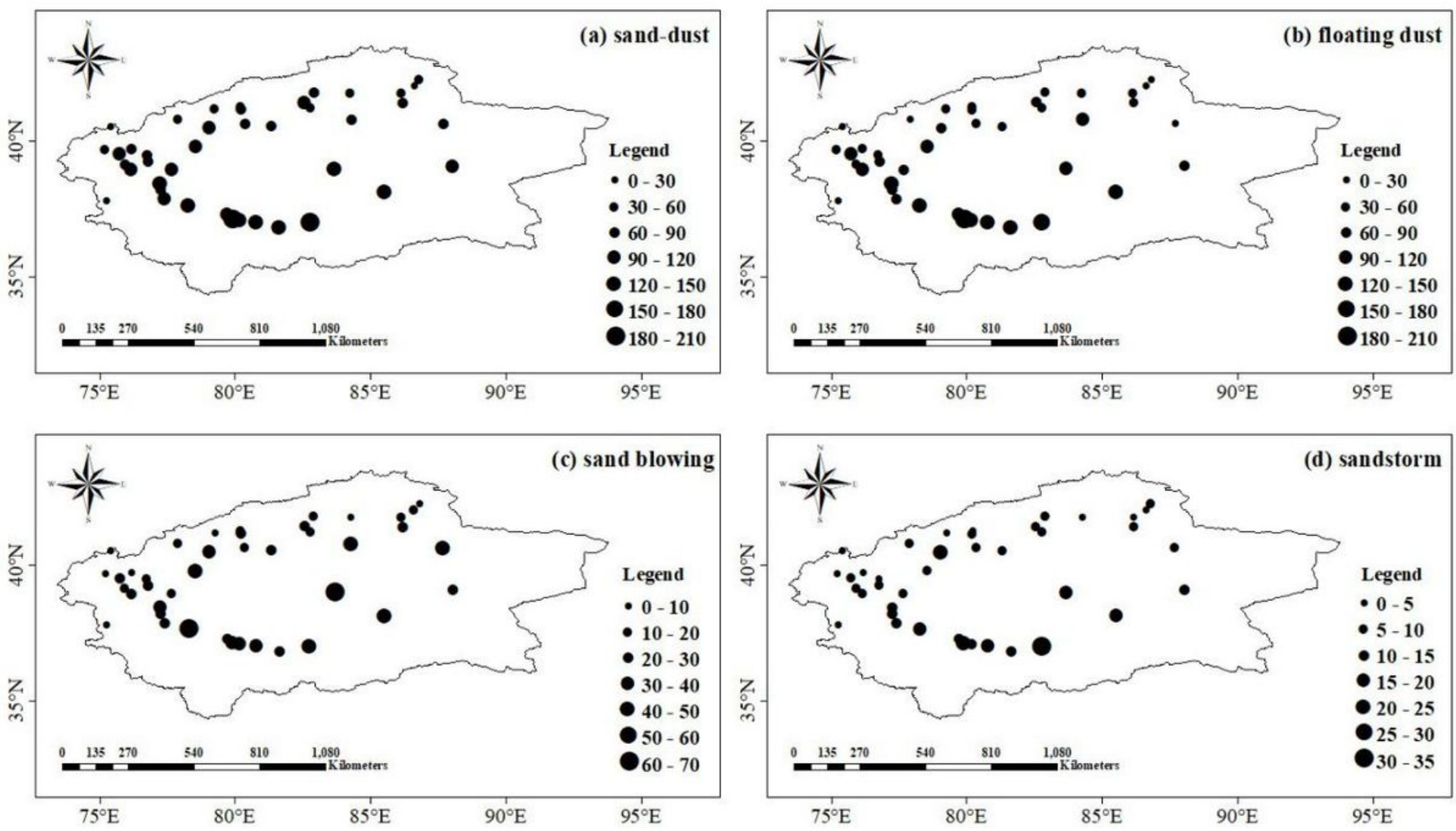

Figure 2

Annual average sand-dust days, floating dust days, sand blowing days, and sandstorm days from 1961 to 2015 in TB. 

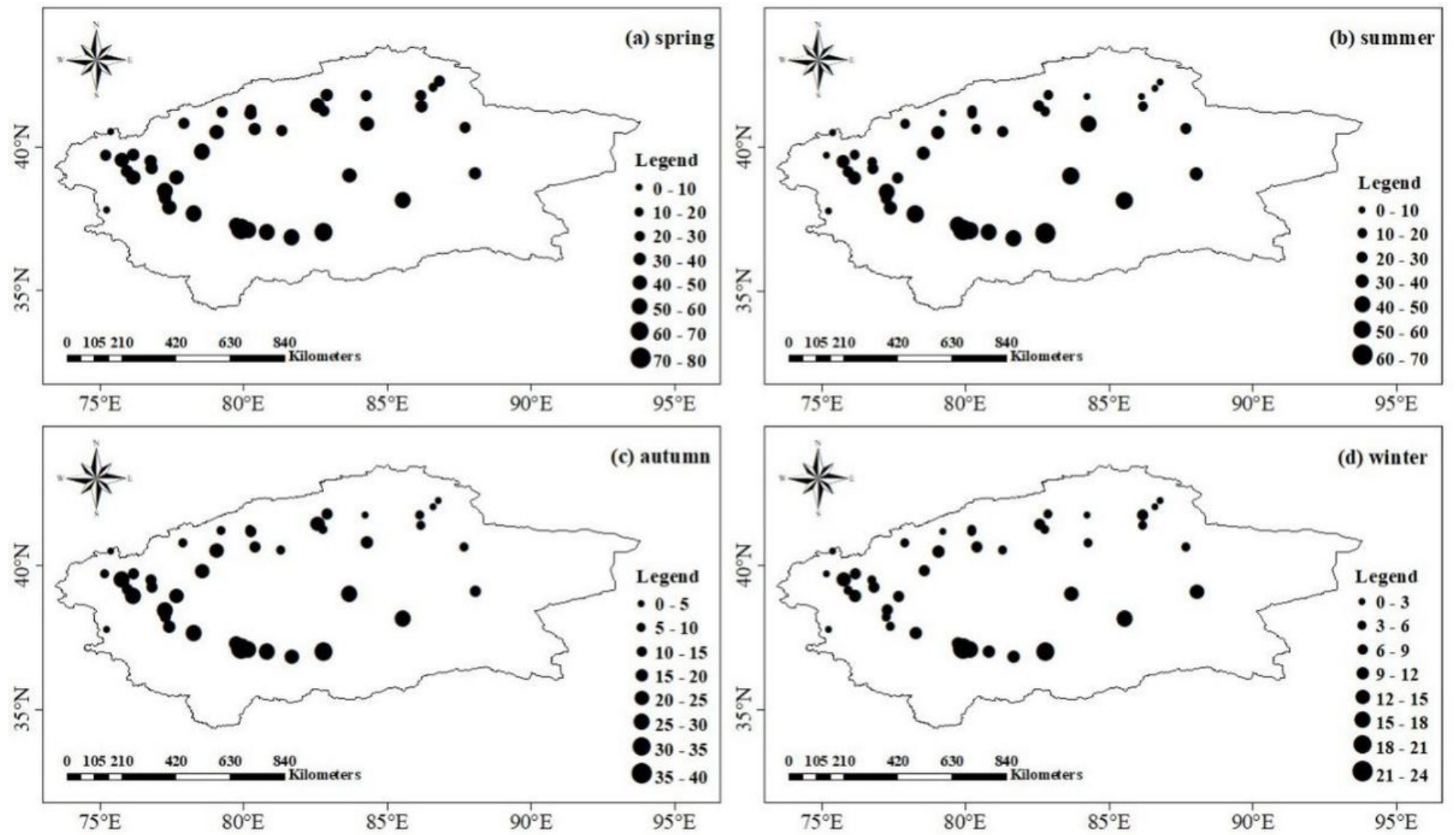

Figure 3

Seasonal average sand-dust days from 1961 to 2015 in TB.
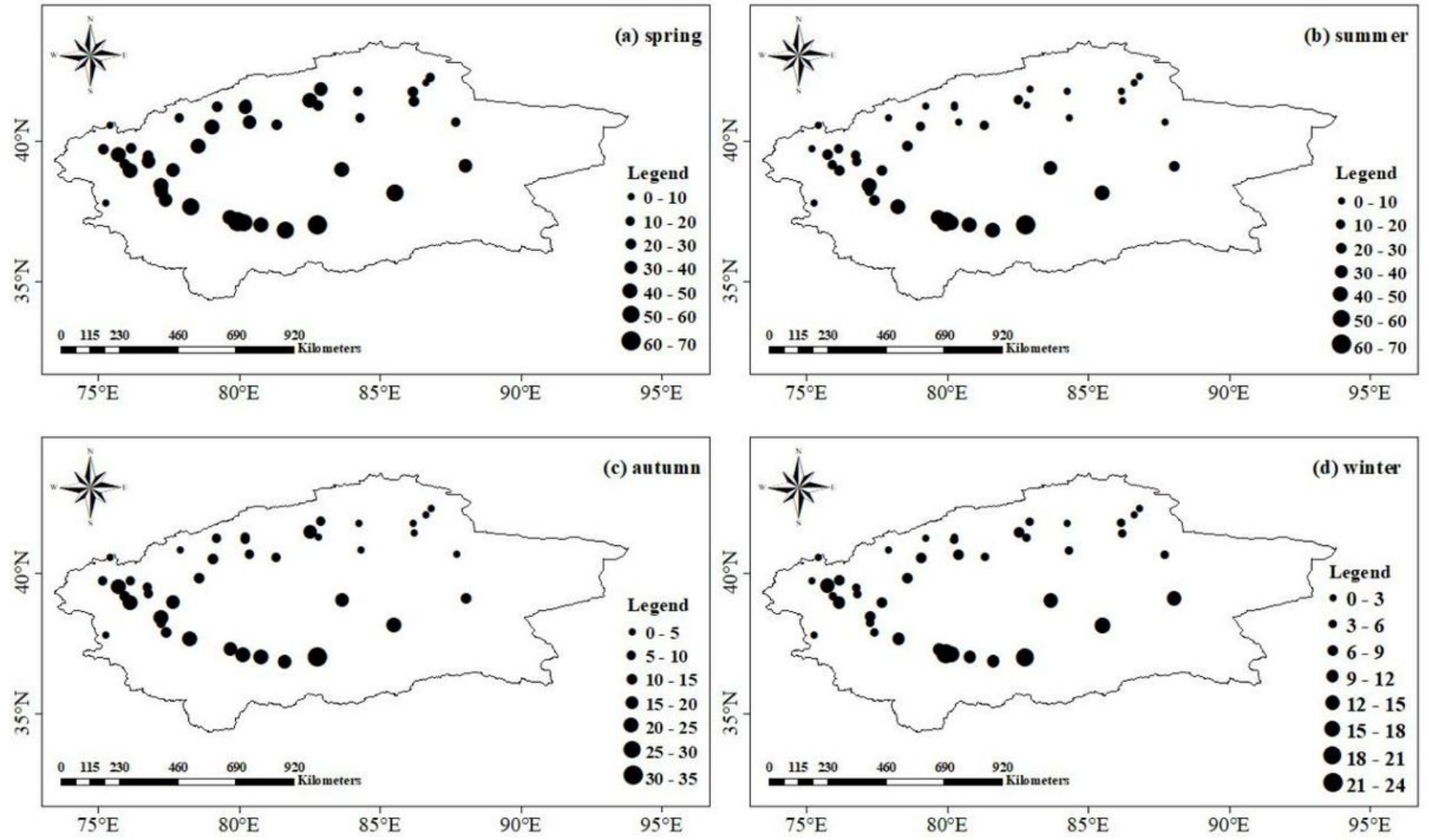

Figure 4 

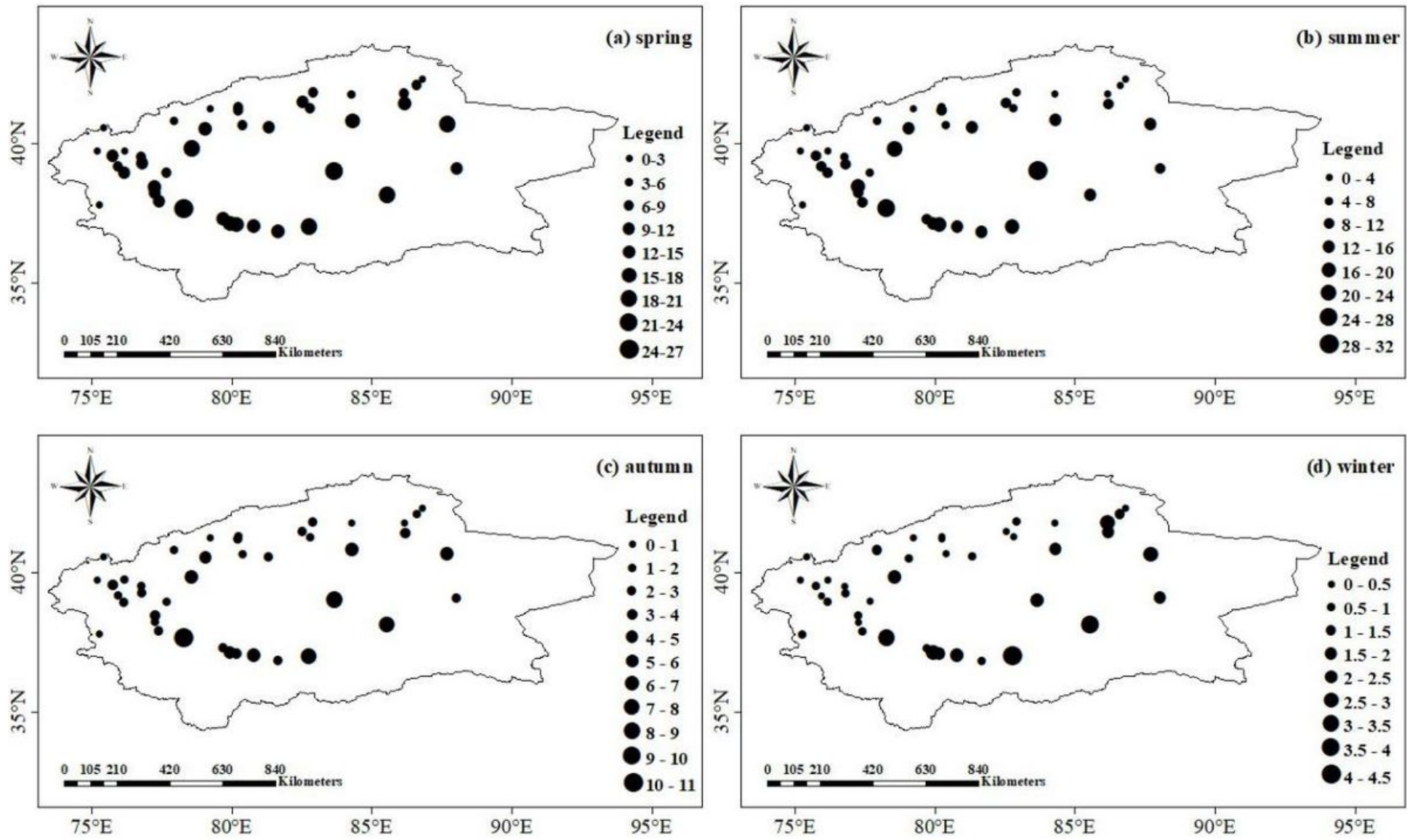

Figure 5

Seasonal average sand-blowing days from 1961 to 2015 in TB.
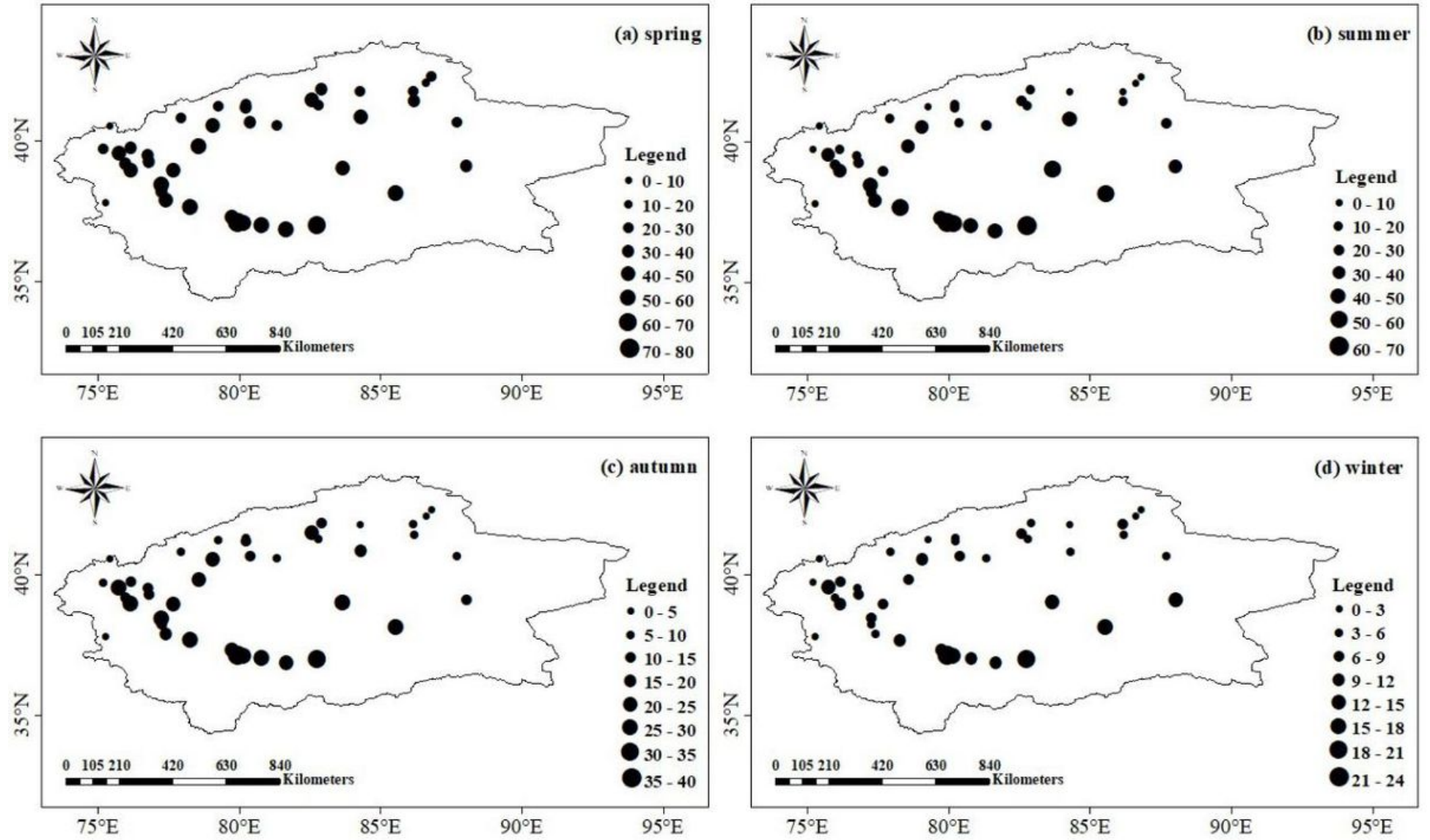
Seasonal average sandstorm days from 1961 to 2015 in TB.
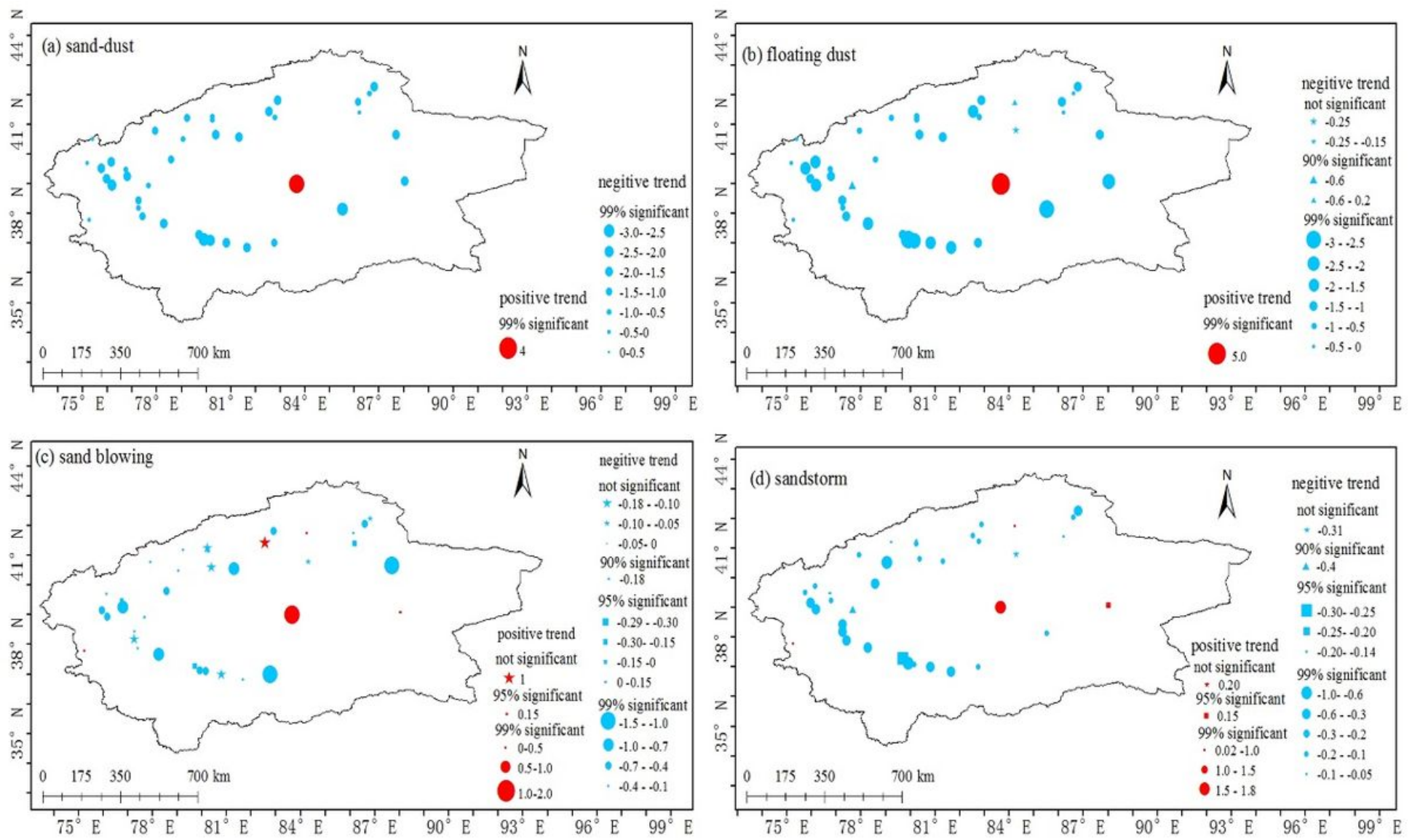

Figure 7

Annual average linear trend rates of sand-dust days, floating dust days, sand blowing days and sandstorm days from 1961 to 2015 in TB. 

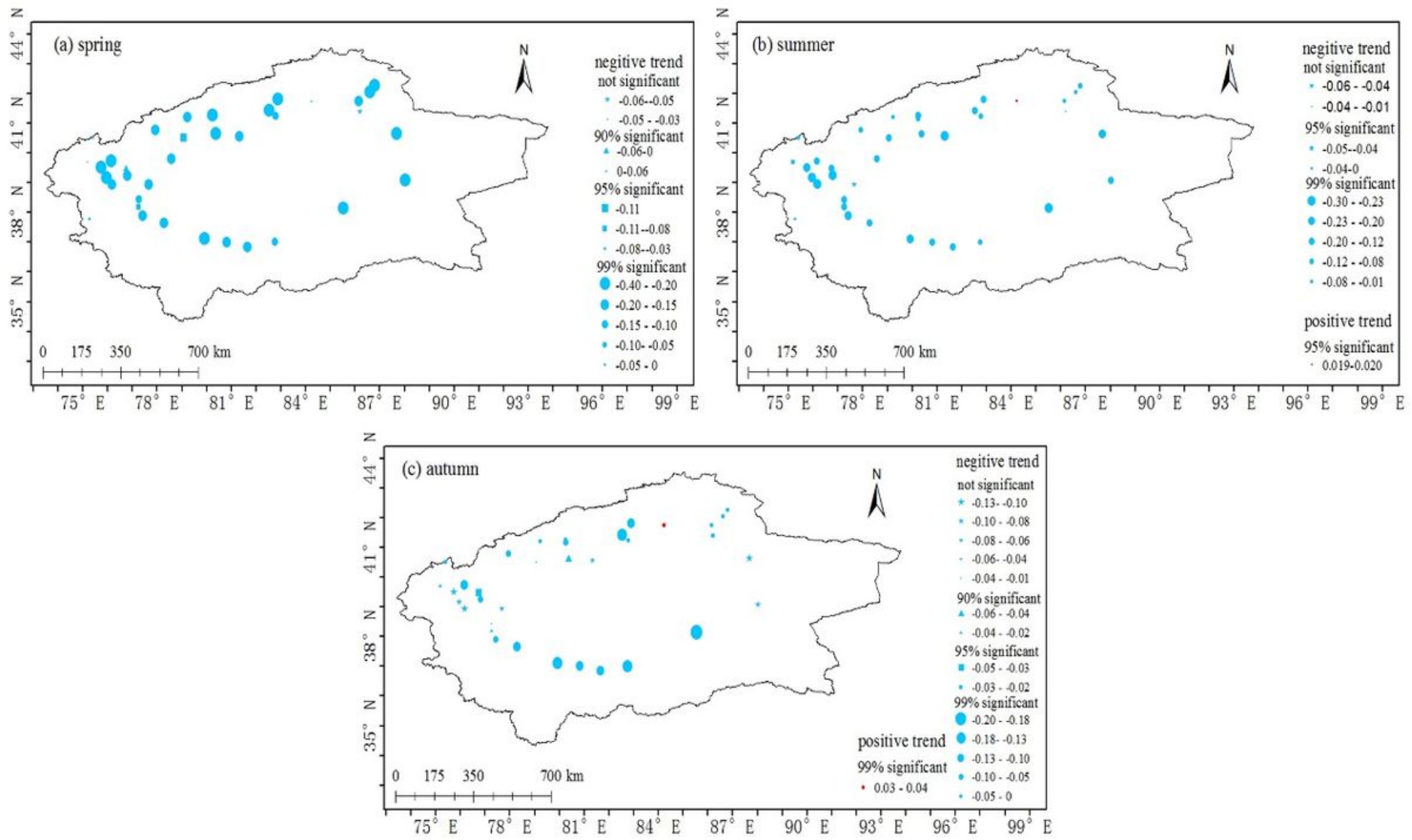

Figure 8

Seasonal average linear trend rates of sand-dust days from 1961 to 2015 in TB.
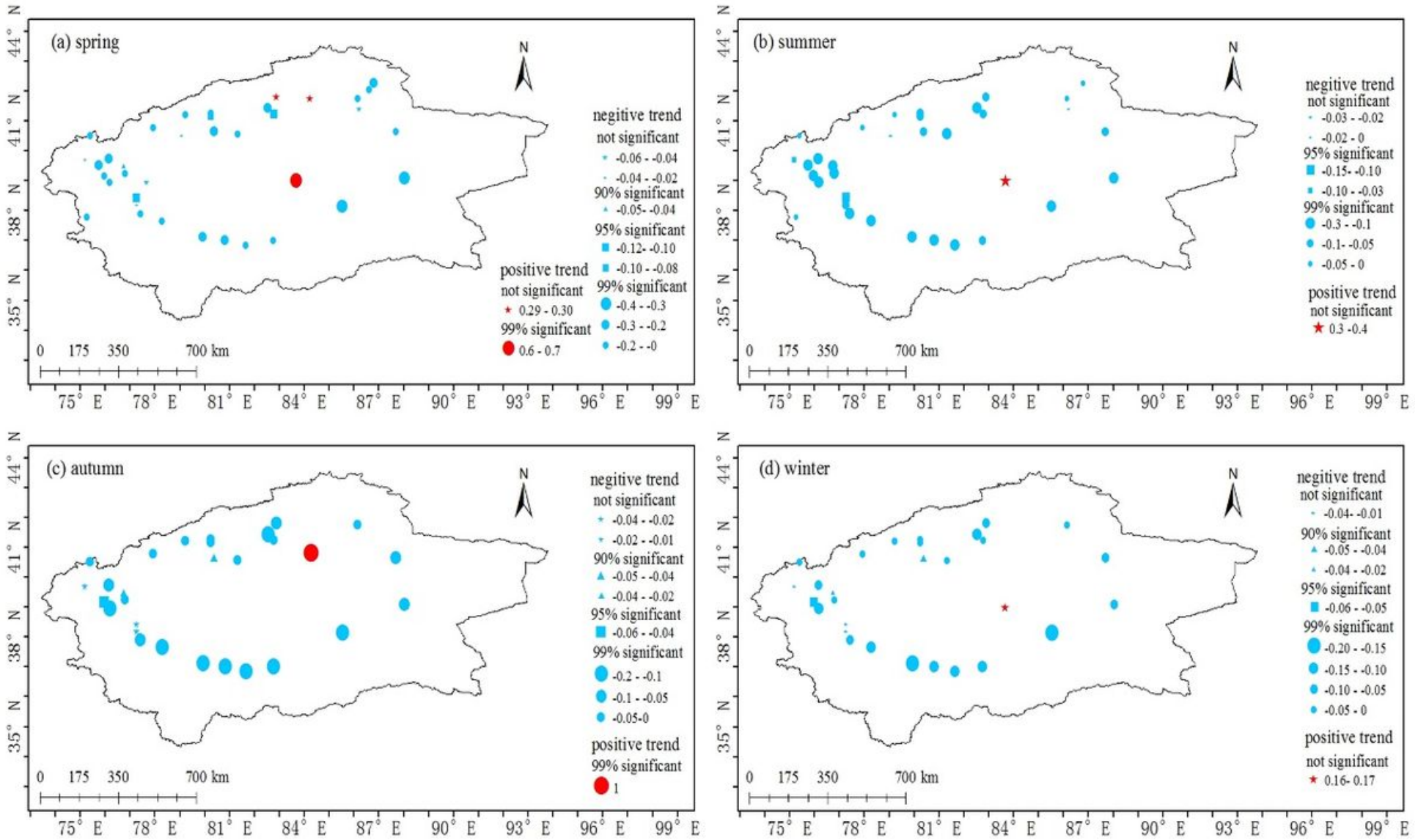
Seasonal average linear trend rates of floating-dust days from 1961 to 2015 in TB.
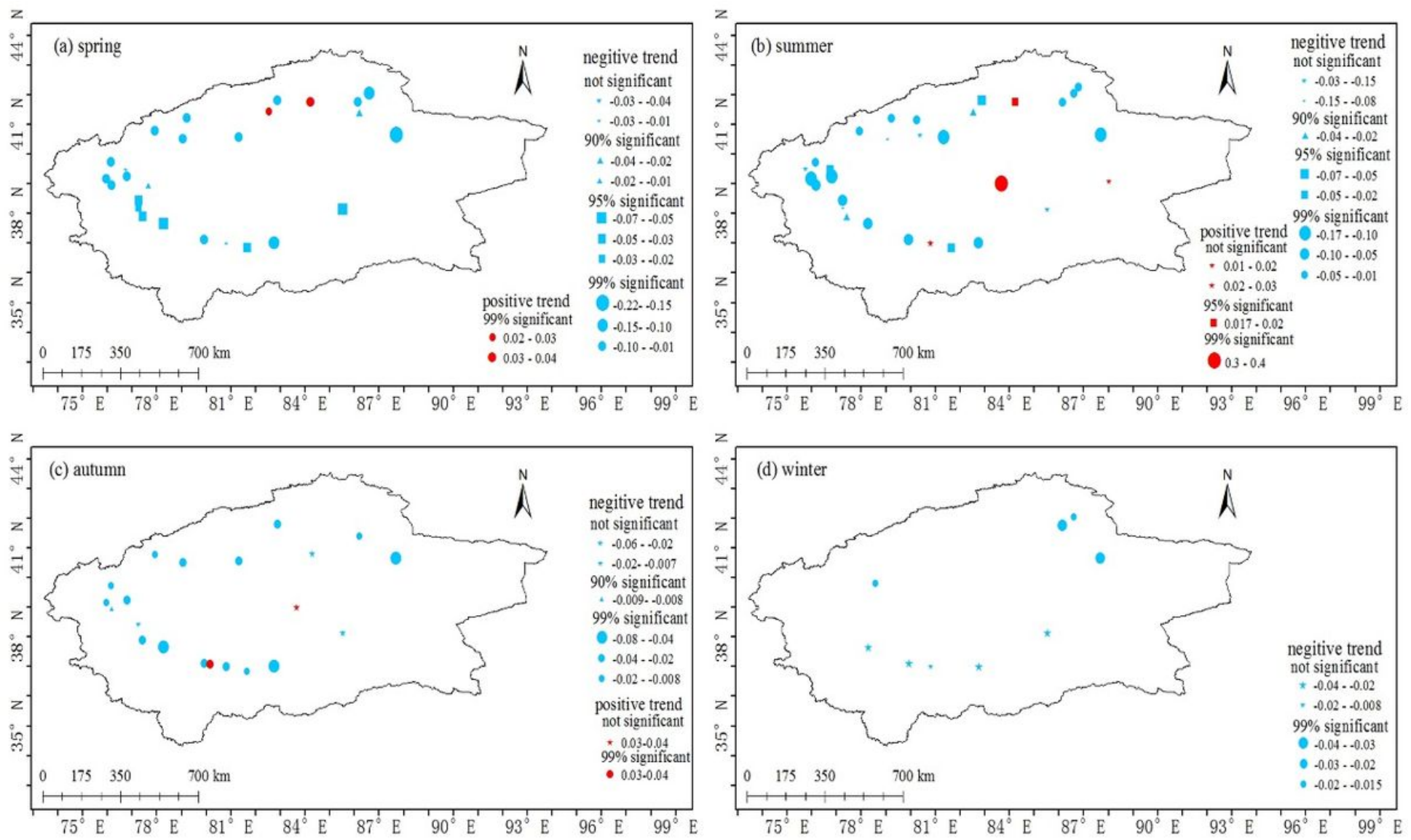

Figure 10

Seasonal average linear trend rates of sand-blowing days from 1961 to 2015 in TB. 

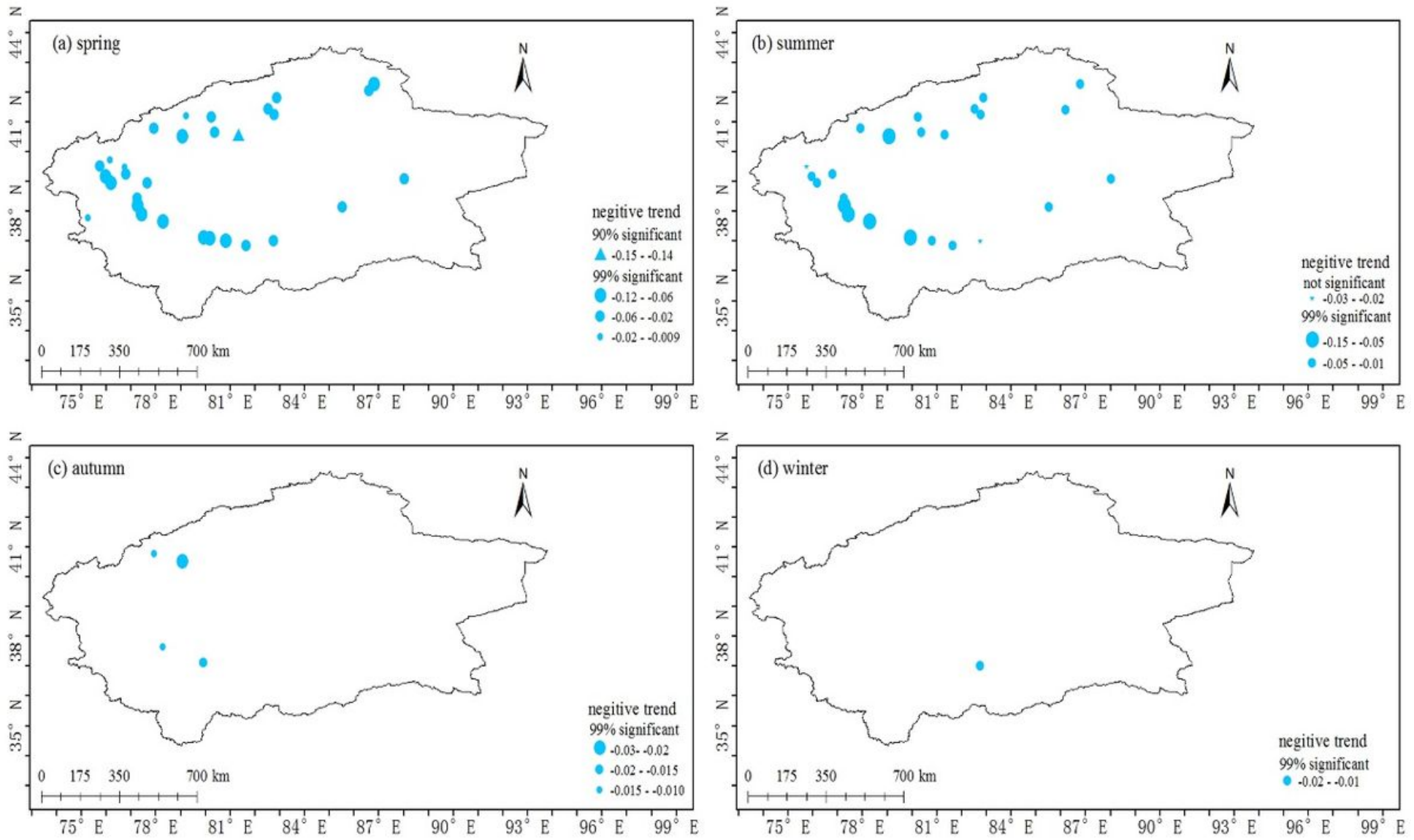

\section{Figure 11}

Seasonal average linear trend rates of sandstorm days from 1961 to 2015 in TB.
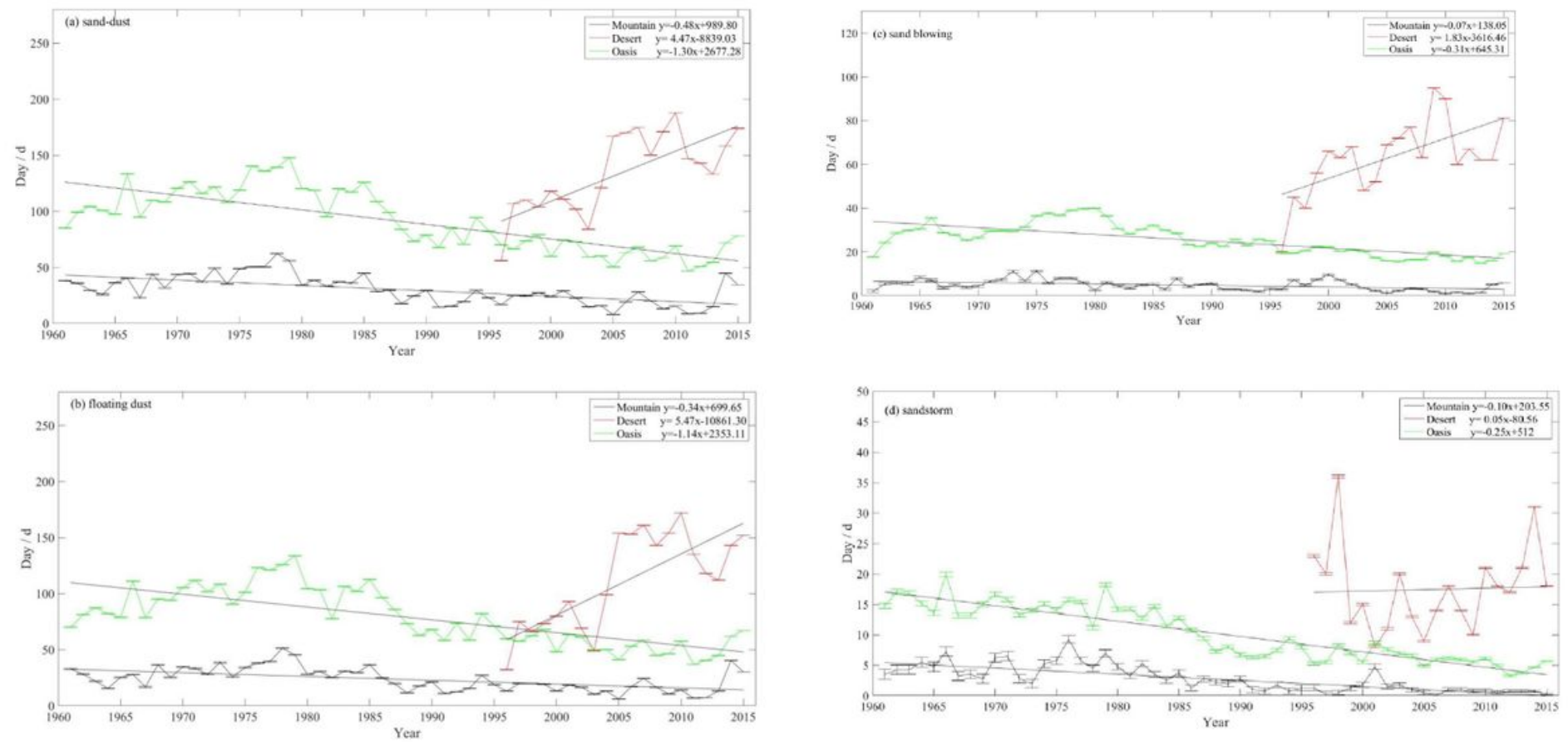

Figure 12

Interannual variations of sand-dust days, floating dust days, sand blowing days, and sandstorm days from 1961 to 2015 in mountainous regions, desert regions, and oasis regions in TB. 

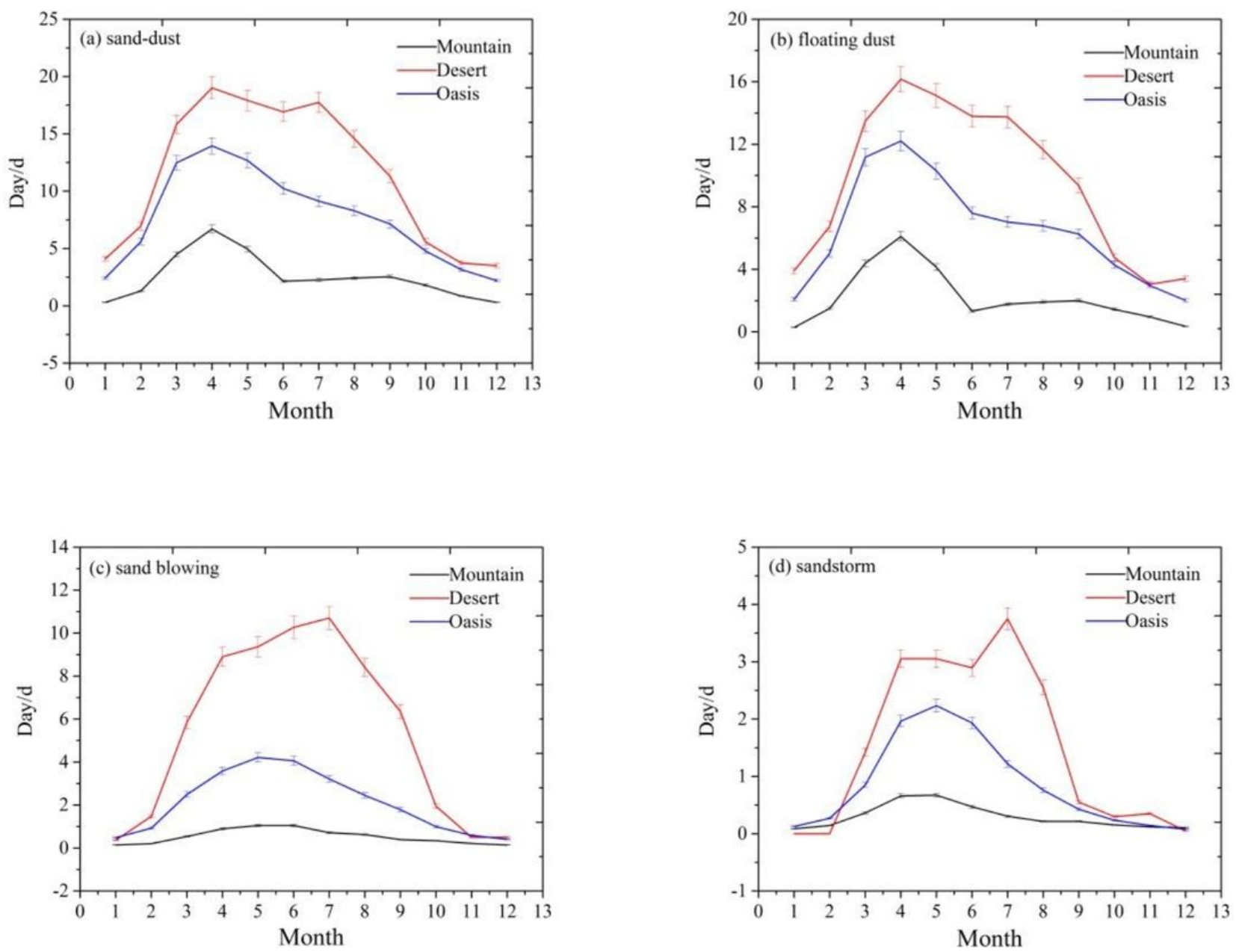

Figure 13

Annual variations of sand-dust days, floating dust days, sand blowing days, and sandstorm days from 1961 to 2015 in mountainous regions, desert regions, and oasis regions in TB. 


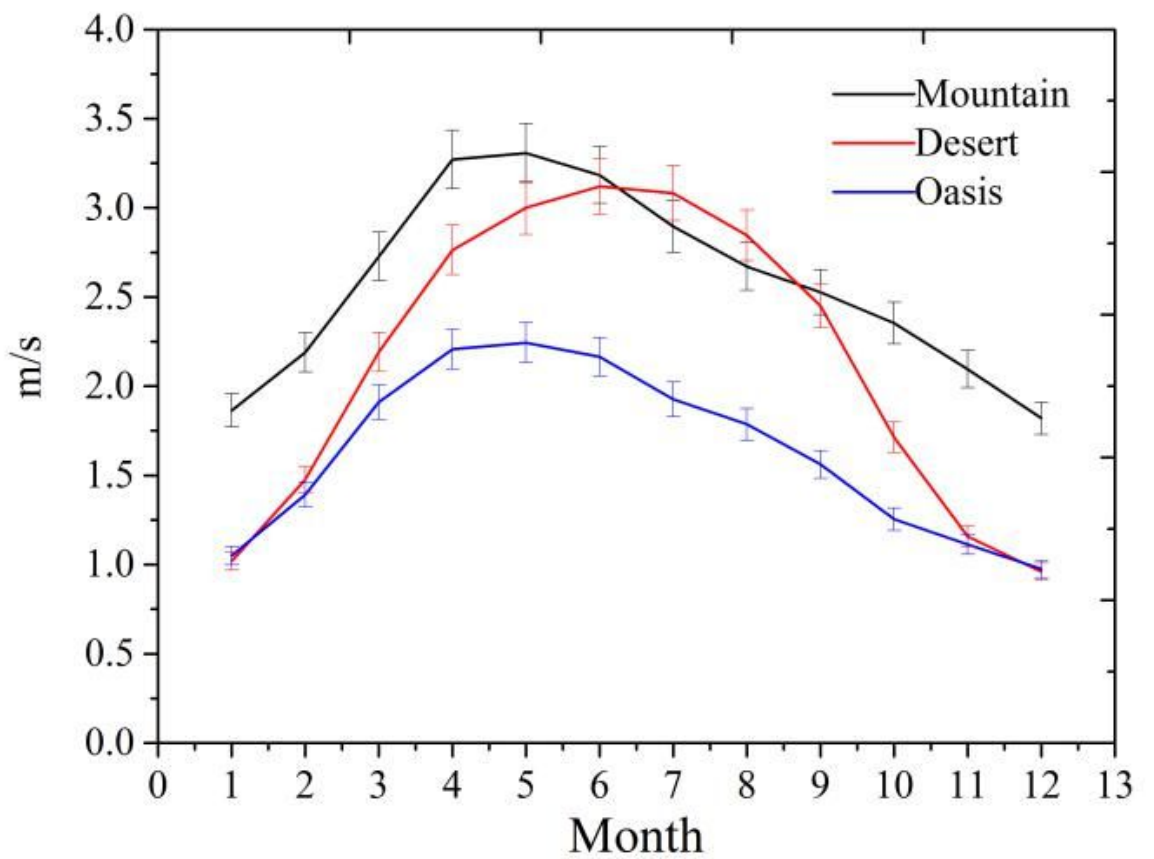

Figure 14

Annual variations of wind speeds from 1961 to 2015 in mountainous regions, desert regions, and oasis regions in TB. 